\title{
THE EFFECTS OF CASTRATION AND ANDROGEN REPLACEMENT THERAPY ON THE ABILITY OF THE MALE TO INFLUENCE THE OESTROUS CYCLE OF THE UNDERFED RAT
}

\author{
MAXINE GRIFFITHS, K. J. COOPER AND D. B. CRIGHTON \\ University of Nottingham School of Agriculture, \\ Sutton Bonington, Loughborough, Leicestershire
}

(Received 29th March 1972, accepted 25th April 1972)

It is established that stimuli associated with the presence of a sexually mature male can influence the oestrous cycle of the underfed rat (Cooper \& Haynes, 1967). This effect is still present when physical contact between the sexes is prevented, the lengthened and irregular cycles characteristic of undernutrition becoming significantly shorter (McNeilly, Cooper \& Crighton, 1970; Purvis, Cooper \& Haynes, 1971). A similar response to the proximity of the male has been demonstrated in the mouse, the lengthened and irregular oestrous cycles usually observed when mice are grouped not being found in the presence of a male (Whitten, 1957). Castration of the male prevented the acceleration of oestrous behaviour, but the stimulus value of the male for the female returned following androgen therapy (Bronson \& Whitten, 1968). The object of the work described here was to determine whether the reduction in oestrous cycle duration induced in underfed rats by the proximity of a male was also androgendependent.

All the rats used were weaned at 21 days of age and housed in groups of ten to twelve in large communal cages until selection. The female rats were allocated to the experiments when they were approximately 5 months of age and weighed 150 to $200 \mathrm{~g}$. The male rats were selected at approximately 6 months of age and weighed 250 to $300 \mathrm{~g}$. Castration of a number of males was carried out when they were 28 days old. During the experimental period, all animals were housed individually in metal battery cages. Each cage was divided into two equal parts by means of a wire barrier as described by McNeilly et al. (1970) in order to minimize direct physical contact between animals.

Two experiments were carried out. In Exp. 1, forty female rats were allocated at random to the following treatment groups: ten animals were allowed unrestricted access to food. The remaining thirty animals were subjected to a restricted dietary regimen consisting of $65 \%$ by weight of the mean daily food consumption of the unrestricted group. Ten of these animals were fed this restricted diet only, ten were underfed in proximity to intact males and ten were underfed in proximity to castrate males. For Exp. 2, twenty female rats were allocated at random to two treatment groups. Ten animals were fed a restricted diet as described in Exp. 1 in proximity to an intact male and the 
remaining ten animals were underfed in proximity to a castrate male which had been given a subcutaneous injection of testosterone propionate $(30 \mu \mathrm{g} / 100 \mathrm{~g}$ body weight) each day for a period of 14 days preceding introduction to the cages in which the females were housed.

From the time of the first vaginal smear, all females were allowed to complete two oestrous cycles on an unrestricted feed intake and the underfed females completed either two or three (Exp. 1) or three (Exp. 2) oestrous cycles when subjected to dietary restriction. Thus, changes in dietary regimen were made

TABle 1

DURATIONS OF OESTROUS GYCLE IN RATS (EXPERIMENT 1)

\begin{tabular}{l|c|c|c|c}
\hline \multirow{2}{*}{ Sequential treatments } & \multicolumn{3}{|c}{ Duration of oestrous cycle (days) } \\
\cline { 2 - 5 } & \multicolumn{2}{|c}{ Exposed to males } & \multicolumn{2}{c}{ Controls } \\
\cline { 2 - 5 } & \multicolumn{2}{|c|}{$\begin{array}{c}\text { Underfed } \\
\text { throughout }\end{array}$} & $\begin{array}{c}\text { Unrestricted } \\
\text { throughout }\end{array}$ \\
\hline Unrestricted feeding for two & $4 \cdot 2 \pm 0 \cdot 40$ & $3 \cdot 6 \pm 0 \cdot 24$ & $4 \cdot 6 \pm 0 \cdot 18$ & $4 \cdot 1 \pm 0 \cdot 24$ \\
oestrous cycles & $4 \cdot 6 \pm 0 \cdot 18$ & $4 \cdot 1 \pm 0 \cdot 20$ & $4 \cdot 0 \pm 0 \cdot 24$ & $4 \cdot 8 \pm 0 \cdot 20$ \\
Underfeeding for two oestrous & $5 \cdot 3 \pm 0 \cdot 29$ & $5 \cdot 0 \pm 0 \cdot 41$ & $4 \cdot 9 \pm 0 \cdot 35$ & $4 \cdot 0 \pm 0 \cdot 21$ \\
cycles & $5 \cdot 0 \pm 0 \cdot 34$ & $5 \cdot 3 \pm 0 \cdot 29$ & $4 \cdot 6 \pm 0 \cdot 31$ & $4 \cdot 6 \pm 0 \cdot 26$ \\
\hline & Intact males & Castrate males & & \\
Underfeeding + male for one & $3 \cdot 7 \pm 0 \cdot 29$ & $5 \cdot 6 \pm 0 \cdot 41$ & $5 \cdot 8 \pm 0 \cdot 43$ & $4 \cdot 3 \pm 0.24$ \\
oestrous cycle & & & & $4 \cdot 5 \pm 0 \cdot 34$ \\
\hline
\end{tabular}

TABLE 2

DURATIONS OF OESTROUS CYCLE IN RATS (EXPERIMENT 2)

\begin{tabular}{|c|c|c|}
\hline Sequential treatments & \multicolumn{2}{|c|}{ Duration of oestrous cycle (days) } \\
\hline $\begin{array}{l}\text { Unrestricted feeding for two } \\
\text { oestrous cycles }\end{array}$ & $\begin{array}{l}4 \cdot 0 \pm 0 \cdot 15 \\
4 \cdot 2 \pm 0 \cdot 26\end{array}$ & $\begin{array}{l}4 \cdot 5 \pm 0 \cdot 22 \\
4 \cdot 4 \pm 0 \cdot 43\end{array}$ \\
\hline $\begin{array}{l}\text { Underfeeding for three oestrous } \\
\text { cycles }\end{array}$ & $\begin{array}{l}4.9 \pm 0.46 \\
5.0 \pm 0.71 \\
5.0 \pm 0.56\end{array}$ & $\begin{array}{l}5.9 \pm 0.71 \\
7.2 \pm 0.75 \\
6.9 \pm 0.51\end{array}$ \\
\hline $\begin{array}{l}\text { Underfeeding }+ \text { male for one } \\
\text { oestrous cycle }\end{array}$ & $\begin{array}{l}\text { Intact males } \\
3 \cdot 8 \pm 0 \cdot 28\end{array}$ & $\begin{array}{c}\text { Castrate males after } \\
\text { androgen therapy } \\
4 \cdot 3 \pm 0 \cdot 33\end{array}$ \\
\hline
\end{tabular}

at different stages in the cycle in different individuals. The males were placed in proximity to the females following this period of four or five oestrous cycles for the duration of one cycle, introduction being made on the day of metoestrus in each case, following which the experiment was terminated. The males were introduced into the battery cages overnight for a total of $15 \mathrm{hr}$ (from 18.00 to 09.00 hours) in each $24 \mathrm{hr}$, the pattern previously established by Cooper \& Haynes (1967) and McNeilly et al. (1970). During the intervening period, all males were housed in communal cages and selected at random for introduction to the cages of the females each evening since previous work showed that females 
appeared to become less sensitive to the presence of a particular male with time (McNeilly et al., 1970). Oestrous cycles were monitored by the examination of daily vaginal smears.

The results of the two experiments are summarized in Tables 1 and 2 . Statistical evaluations were by analysis of variance. Underfeeding for two oestrous cycles caused an overall significant increase in cycle length $(P<0.05)$. The proximity of intact males for one oestrous cycle significantly shortened this cycle length to a value more closely associated with that found in unrestricted animals $(P<0 \cdot 01)$. This response to the male was not observed when underfed females were in proximity to castrate males, but was obtained with castrate males following the period of androgen replacement therapy $(P<0 \cdot 01)$.

The experiments described confirm the observation of Cooper \& Haynes (1967) and McNeilly et al. (1970) that a marked shortening of the duration of the oestrous cycle occurs when an underfed rat is placed in proximity to a male. The ability of the male to induce the acceleration of oestrus is dependent upon the presence of testes, the response not being apparent after castration. The finding that androgen replacement therapy is able to restore the stimulus value of the male for the female is similar to that in experiments carried out on mice (Bronson \& Whitten, 1968) and indicates that whatever mechanism is responsible for the normal expression of male sexual stimuli, it is probably to a large extent dependent upon testicular steroid secretion. It is not possible to state with certainty the exact nature of the stimulus which can be transmitted from one animal to another under conditions where physical contact was not completely excluded but it seems likely, on the basis of comparable experiments carried out with mice, that this is largely pheromonal.

\section{REFERENCES}

Bronson, F. H. \& Whitten, W. K. (1968) Oestrus-accelerating pheromone in mice: assay, androgen dependency and presence in bladder urine. 7. Reprod. Fert. 15, 131.

Cooper, K. J. \& HAynes, N. B. (1967) Modification of the oestrous cycle of the underfed rat associated with the presence of the male. 7. Reprod. Fert. 14, 317.

Maneilly, A. S., Cooper, K. J. \& Crighton, D. B. (1970) Modification of the oestrous cycle of the underfed rat induced by the proximity of a male. 7. Reprod. Fert. 22, 359.

Purvis, K., Cooper, K. J. \& Haynes, N. B. (1971) The influence of male proximity and dietary restriction on the oestrous cycle of the rat. $\mathcal{F}$. Reprod. Fert. 27, 167.

Whitten, W. K. (1957) Modification of the oestrous cycle of the mouse by external stimuli associated with the male. Changes in the oestrous cycle determined by vaginal smears. F. Endocr. 17, 307. 